\title{
Characterization of Two Cucumber mosaic virus Isolated from Solanum mammosum and Nicotiana affinis
}

\section{Tamashiro, Marcela A}

Laboratory of Plant Pathology, Division of Plant Pathology and Pesticide Science, Department of Applied Genetics and Pest Management, Graduate School of Bioresource and Bioenvironmental

Sciences, Kyushu University

\section{Takeshita, Minoru}

Laboratory of Plant Pathology, Division of Plant Pathology and Pesticide Science, Department of Applied Genetics and Pest Management, Faculty of Agriculture, Kyushu University

\section{Furuya, Naruto}

Laboratory of Plant Pathology, Division of Plant Pathology and Pesticide Science, Department of Applied Genetics and Pest Management, Faculty of Agriculture, Kyushu University

Takanami, Yoichi

Laboratory of Plant Pathology, Division of Plant Pathology and Pesticide Science, Department of Applied Genetics and Pest Management, Faculty of Agriculture, Kyushu University

https://doi.org/10.5109/4584

出版情報：九州大学大学院農学研究院紀要. 49 (2)，pp. 243-252，2004-10-01. Faculty of Agriculture, Kyushu University

バージョン：

権利関係: 


\title{
Characterization of Two Cucumber mosaic virus Isolated from Solanum mammosum and Nicotiana affinis
}

\author{
Marcela A. TAMASHIRO', Minoru TAKESHITA, Naruto FURUYA \\ and Yoichi TAKANAMI*
}

\author{
Laboratory of Plant Pathology, Division of Plant Pathology and Pesticide Science, \\ Department of Applied Genetics and Pest Management, Faculty of Agriculture, \\ Kyushu University, Fukuoka 812-8581, Japan. \\ (Received June 24, 2004 and accepted July 13, 2004)
}

\begin{abstract}
Two Cucumber mosaic virus (CMV) isolates, CMV-NA from Nicotiana affinis, and CMV-SM from Solanum mammosum (nipple fruit plant) inducing mild and severe systemic mosaic symptoms, respectively, on tobacco (Nicotiana tabacum cv. Xanthi-nc), were characterized on the basis of their nucleotide and amino acid sequences of RNA3, serology and host ranges. The complete nucleotide sequencing of RNA3s of CMV-NA and CMV-SM has been done. Multiple alignment analysis of the nucleotide sequences of RNA3 of the 5'noncoding region and amino acid sequences of the CP and MP revealed that, CMV-NA and CMV-SM belong to subgroup I. CMV-NA induced systemic infection on Cryptotaenia japonica and caused severe leaf malformation, but CMV-SM could not infect this plant. $N$. occidentalis inoculated mechanically with CMV-SM developed mild mosaic symptoms, while CMV-NA was unable to induce systemic infection on this plant. Thus, $C$. japonica and $N$. occidentalis are strain specific hosts for CMV-NA and CMV-SM, respectively. Raphanus sativus cv. Akidumari and Phaseolus vulgaris demonstrated to be non-host plants of CMV-NA and CMV-SM. This is the first report of a CMV strain infecting $N$. affinis in the field.
\end{abstract}

\section{INTRODUCTION}

Cucumber mosaic virus (CMV) is one of the most widespread and economically important plant viruses known (Zhang et al., 1994; Palukaitis et al., 1992), infecting more than 800 species in over 70 families (Grieco et al.; 1997). CMV is the type species of the genus Cucumovirus (family Bromoviridae), with particles characterized by $29 \mathrm{~nm}$ icosahedron encapsidating a single-stranded plus sense RNA, which has a functionally divided genome namely RNA1, 2 and 3 (Palukaitis et al., 1992). Proteins translated from RNAs 1 and 2 are associated with viral genome replication (Nitta et al., 1988). RNA1 has one open reading frame (ORF) encoding protein 1a and RNA2 has two ORFs, which encode protein $2 \mathrm{a}$ and protein $2 \mathrm{~b}$. RNA 3 has also two ORFs which encode the movement protein (MP) and the coat protein (CP). Both proteins are essential for cell-to-cell and the long distance movement of the virus (Suzuki et al., 1991).

Many isolates of CMV have been described on the basis of a broad range of diverse phenotypes encompassing host range and symptomatology (Palukaitis et al., 1992).

1 Laboratory of Plant Pathology, Division of Plant Pathology and Pesticide Science, Department of Applied Genetics and Pest Management, Graduate School of Bioresource and Bioenvironmental Sciences, Kyushu University

* Corresponding author (E-mail: takanami@agr.kyushu-u.ac.jp) 
Serological data, peptide mapping of the $\mathrm{CP}$, and nucleic acid hybridization divided CMV strains into subgroups I and II (Roossinck et al., 1999). Particular attention was drawn to map the determinants of CMV pathogenicity (Carrere et al., 1999). It has been experimentally proved that a single amino acid change in the CP can direct symptom expression on tobacco (Shintaku et al., 1992; Suzuki et al., 1995) and determine the stunting of $N$. glutinosa (Szilassy, 1999) as well as local symptom expression and systemic movement (Kobori et al., 2002). Experimental data indicate that MP may also influence symptom severity by modulating the rate of both local and systemic movement (Moreno et al., 1997). CMV produces different symptoms in various host plants depending on the virus strains (Kaper and Waterworth, 1981). Different virus strains may also differ in the host range and vector transmissibility, affecting their epidemiology and eventual control (Walkey, 1999).

Although considerable advances have been made to understand the molecular biology and biochemistry of plant viruses, the discovery of new strains and their characterization is still important in elucidating the complex mechanisms involved in symptoms expression and disease development.

We found Solanum mammosum (nipple fruit plant) and Nicotiana affinis plants showing mosaic symptoms in the field. Both $S$. mammosum and $N$. affinis, are important ornamentals plants throughout the world. S. mammosum plants are mainly produced by vegetative propagation, which makes the transmission of viruses a potentially serious problem (Adkins and Kamenova, 2003). The causal agents of these two plants were suspected to be CMV by preliminary experiments such as inoculation to several indicating plants, electronmicroscopy, etc.

The objective of this study is the characterization of two CMV strains isolated from $S$. mammosum and $N$. affinis plants at a molecular level and by the symptomatology induced in their host plants.

\section{MATERIALS AND METHODS}

\section{Virus isolates and virus propagation}

In November 2002, S. mammosum and N. affinis plants showing virus like symptoms were collected at Chikushino city, Fukuoka Prefecture. The CMV isolates from $S$. mammosum and $N$. affinis herein designated CMV-SM and CMV-NA, respectively, were propagated in tobacco ( $N$. tabacum cv. Xanthi-nc) at $22-28^{\circ} \mathrm{C}$ in an insect-proof greenhouse. Inoculated and upper leaves of the plants were harvested at 7 days post inoculation (d.p.i) and 14 d.p.i, respectively, and samples were kept in a freezer at $-80^{\circ} \mathrm{C}$ for further analysis. Virus was purified essentially as described by Takanami (1981).

\section{Host range studies}

For the host range determination of CMV-NA and CMV-SM, test plants Lagenaria siceraria (bottle gourd), Cucurbita pepo (squash), N. tabacum cv. Xanthi-nc, N. glutinosa, $N$. occidentalis, Lycopersicon esculentum, Chenopodium amaranticolor, $C$. quinoa, Phaseolus vulgaris, Vigna unguiculata (cowpea), Zinnia elegans, Gomphrena globosa, Raphanus sp., R. sativus cv. Akidumari and Cryptotaenia japonica were used. All test plants were grown from seeds under controlled conditions 
in a greenhouse at $25^{\circ} \mathrm{C}$. Purified virus $(100 \mu \mathrm{g} / \mathrm{ml}$ or $1 \mathrm{mg} / \mathrm{ml})$ was rubbed onto carborundum dusted leaves of all the tested plants. Inoculation was made to fully expanded cotyledons of bottle gourd, squash, tomato and both Raphanus plants, primary leaves of cowpea, and to the first true leaves at the 4 leaf stage of $Z$. elegans and $G$. globosa and at 5-7 leaf stage of tobacco plants. Symptoms were recorded and inoculated leaves were taken for serological analysis at 7 days, and second and third upper leaves at 14 days post inoculation (d.p.i) to test local and systemic infection, respectively. If results were negative, samples were taken one month after inoculation and tested again.

\section{Tissue print and RNA hybridization}

Procedures for immuno-tissue print and RNA hybridization were essentially according to Takeshita et al. (1998). In the tissue print analysis nitrocellulose membranes were incubated with a polyclonal antibody against a yellow strain of CMV (CMV-Y) (Tomaru and Hidaka, 1960) overnight at room temperature and after washing the membranes 3 times for 10 minutes with PBS containing 0.1\% Tween 20 and 5\% skimmed milk, samples were incubated for 2 hours with goat anti-rabbit IgG conjugated to alkaline phosphatase. RNA hybridization was assessed using nylon membranes (Hybond- $\mathrm{N}^{+}$, Amersham) and a DIG-labeled probe which recognizes the common 3' terminal portion sequences of all CMV.

\section{RT-PCR, cDNA cloning, subcloning and in vitro transcription of RNA3}

CMV RNA was extracted from purified viral particles following the procedure described by Takanami (1981). Reverse transcription polymerase chain reaction (RT-PCR) was carried out using JT7 and JT4 primers and the construction of full-length cDNA clones of RNA3 and subcloning were performed as described by Takeshita and Takanami (1997). Transcripts were synthesized in vitro essentially according to Suzuki et al. (1991) and thereafter used to inoculate tobacco leaves for infectivity studies.

\section{Sequencing and sequence analysis}

The cDNA clones of CMV RNA3 were sequenced according to the method described by Sanger et al. (1977), using a DSQ-1000 Shimadzu sequencer. Assembly of the complete nucleotide sequences of CMV RNA3s was done using DNASIS (3.3 version, Hitachi). Multiple alignments of the 5'noncoding MP and CP regions, and percent sequence homology were assessed using Genetyx-win (5.2 version) and DNAMAN version 4.0 (Lynnon Biosoft, Quebec, Canada). CMV strains used for sequence comparison were as follows: CMV-Y (D00385), CMV- KM (AB004780) and CMV-Q (M21464) strains.

\section{RESULTS}

\section{Symptoms in tobacco plants}

Tobacco plants infected with CMV-NA or CMV-SM showed remarkable differences in symptom expression. The plants inoculated with CMV-NA showed severe systemic mosaic, while those infected with CMV-SM developed mild systemic mosaic (Fig. 1). 

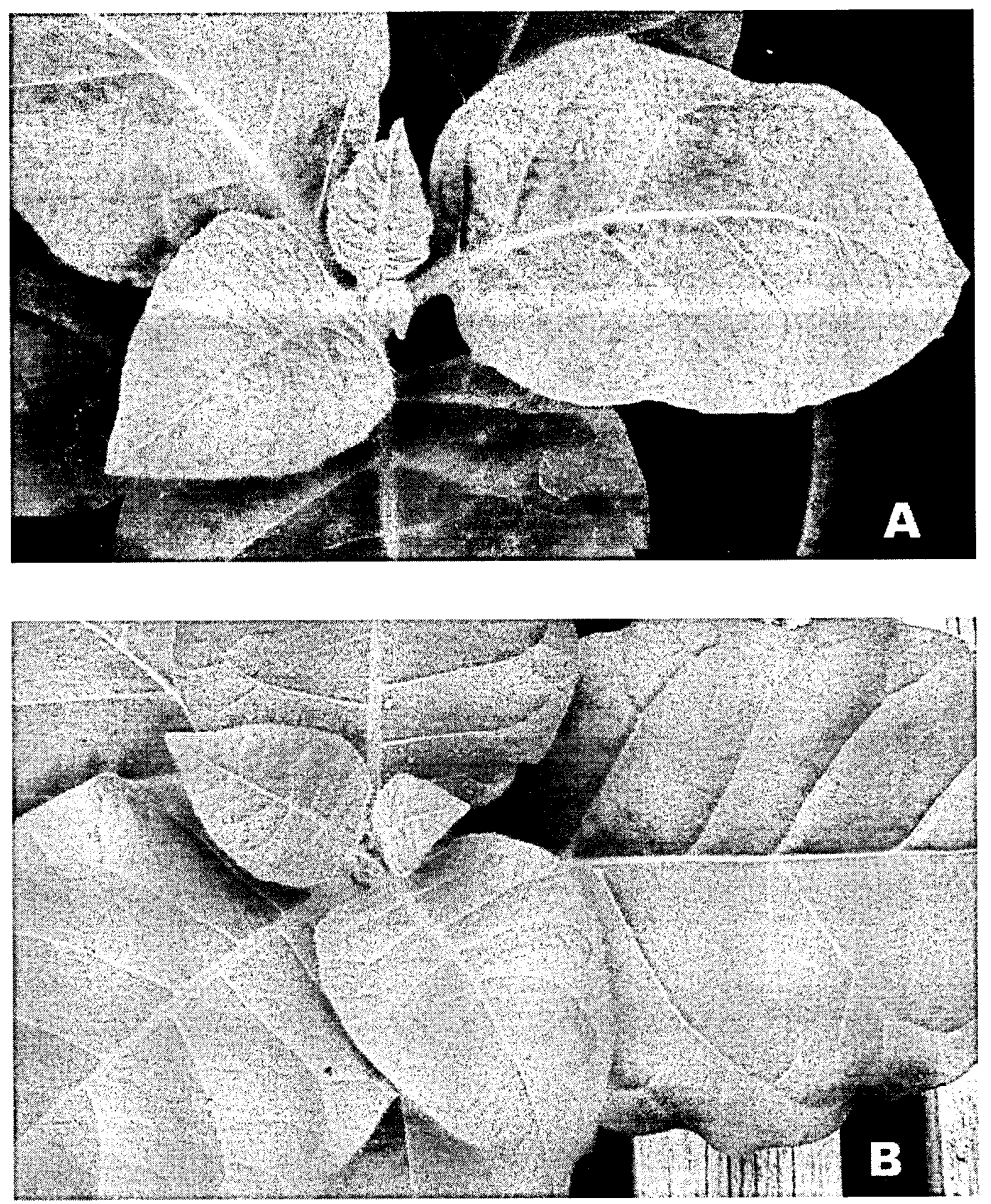

Fig. 1. N. tabacum cv. Xanthi-nc plants infected with CMV-NA (A) or CMV-SM (B) showing severe systemic mosaic or systemic mild mosaic symptoms, respectively, 14 days post inoculation (d.p.i).

\section{Host range, tissue print and RNA hybridization}

CMV-NA and CMV-SM showed significant differences in their host ranges. CMV-SM induced green mild mosaic symptoms on $N$. occidentalis, whereas CMV-NA did not (Table 1). Presence of virus in the tested plants was confirmed by immuno tissue printing (data not shown) and RNA hybridization analysis (Fig. 2). Cryptotaenia plants inoculated with CMV-NA expressed severe leaf malformation on the upper leaves, while CMV-SM did not systemically infect the plants. Both strains induced small and numerous chlorotic spots on the inoculated leaves of bottle gourd. CMV-NA induced systemic chronic mosaic symptoms (SCMS) on the upper leaves of the plants, while CMV-SM occasionally developed small yellow and necrotic spots on the first upper non-inoculated 
Table 1. Reaction of test plants inoculated with CMV-SM or CMV-NA.

\begin{tabular}{llcccc}
\hline & & \multicolumn{4}{c}{ symptoms } \\
\cline { 3 - 6 } Plants & Family & $\begin{array}{c}\text { Inoculated } \\
\text { leaves }\end{array}$ & $\begin{array}{c}\text { Upper } \\
\text { leaves }\end{array}$ & $\begin{array}{c}\text { Inoculated } \\
\text { leaves }\end{array}$ & $\begin{array}{c}\text { Upper } \\
\text { leaves }\end{array}$ \\
\hline Gomphrena globosa & Amarantacea & chl & $\mathrm{m}$ & $\mathrm{chl}$ & $\mathrm{M}$ \\
Cryptotaenia japonica & Apiaceae & - & - & - & $\mathrm{Mal}$ \\
Zinnia elegans & Asteraceae & - & $\mathrm{m}$ & - & $\mathrm{M}$ \\
Raphanus sativus sp. & Brassicaceae & - & $\mathrm{m}$ & - & $\mathrm{m}$ \\
R. sativus cv. akidumari & Brassicaceae & - & - & - & - \\
Chenopodium amaranticolor & Chenopodiaceae & $\mathrm{ns}$ & - & $\mathrm{ns}$ & - \\
C. quinoa & Chenopodiaceae & $\mathrm{ns}$ & - & $\mathrm{ns}, \mathrm{n}$ & - \\
Lagenaria siceraria & Cucurbitaceae & $\mathrm{chls}$ & $(\mathrm{ys})$ & $\mathrm{chls}$ & $\mathrm{SCMS}$ \\
Cucurbita pepo & Cucurbitaceae & - & $\mathrm{m}$ & $\mathrm{ys}$ & $\mathrm{M}$ \\
Phaseolus vulgaris & Fabaceae & (ns) & - & (ns) & - \\
Vigna unguiculata & Fabaceae & $\mathrm{ns}$ & - & $\mathrm{ns}$ & - \\
Lycopersicon esculentum & Solanaceae & - & $\mathrm{m}$ & - & $\mathrm{M}, \mathrm{Mal}$ \\
Nicotiana glutinosa & Solanaceae & - & $\mathrm{m}$ & - & $\mathrm{m}$ \\
N. occidentalis & Solanaceae & - & $\mathrm{m}$ & - & - \\
N. tabacum cv. Xanthi-nc & Solanaceae & - & $\mathrm{m}$ & - & $\mathrm{M}$ \\
\hline
\end{tabular}

chls: chlorotic spots; m: mild mosaic; M: severe mosaic; mal: mild malformation; Mal: severe malformation; n: necrosis; ns: necrotic spots; SCMS: systemic chronic mosaic symptoms; ys: yellow spots; (): occasionally

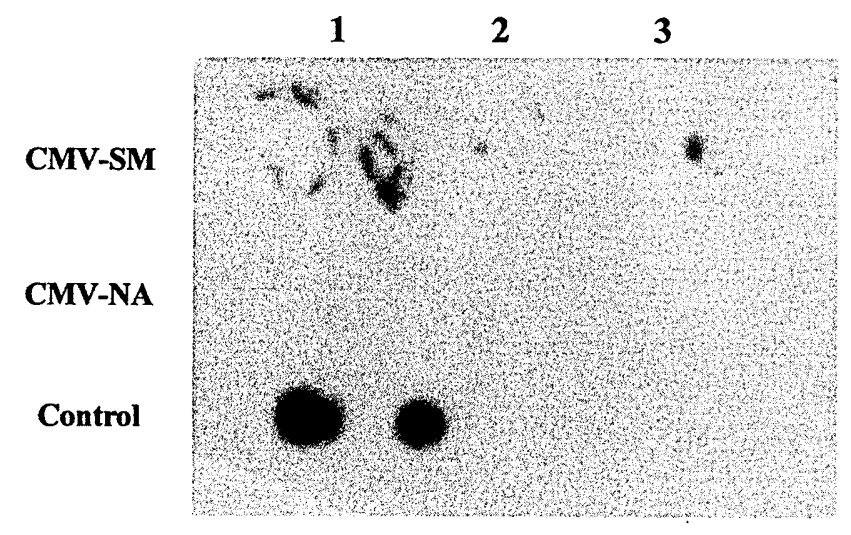

Fig. 2. Detection of CMV in the upper leaves of $N$. occidentalis by RNA hybridization. Numbers on the top represent the individual test plants. The DIG-labeled probe used recognizes the 3'noncoding regions of CMV belonging to subgroup I. Positive control (CMV-NA and -SM, left); negative control (healthy plant, right). 
Table 2. Comparison of the number of nucleotides in RNA3s of CMV-NA and CMV-SM.

\begin{tabular}{ccccccc}
\hline Virus isolate & \multicolumn{5}{c}{ Genomic region } \\
\hline & 5'noncoding & 3a protein & IR $^{\mathrm{a}}$ & Coat protein & 3'noncoding & Total \\
\hline CMV-NA & 120 & $837\left(279 \mathrm{aa}^{\mathrm{b}}\right)$ & 303 & $654\left(218 \mathrm{aa}^{\mathrm{b}}\right)$ & 298 & 2212 \\
CMV-SM & 120 & $837\left(279 \mathrm{aa}^{\mathrm{b}}\right)$ & 301 & $654\left(218 \mathrm{aa}^{\mathrm{b}}\right)$ & 304 & 2216 \\
\hline
\end{tabular}

${ }^{\text {a }}$ Intergenic region

'Amino acid
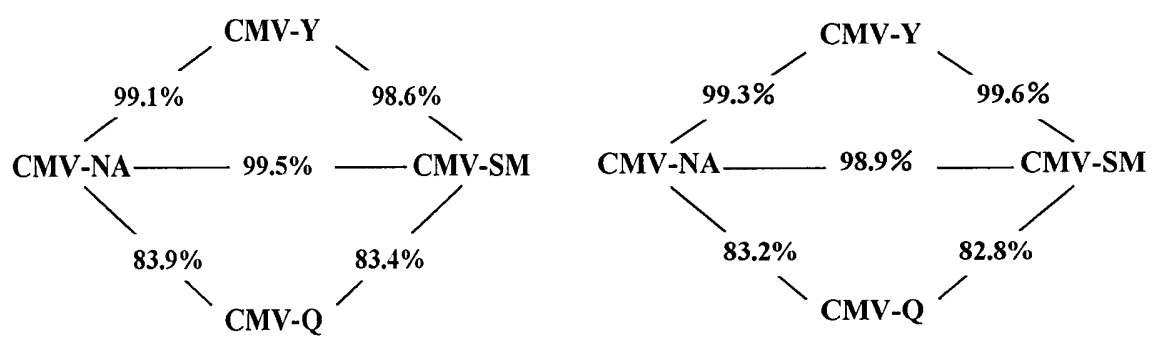

Fig. 3. Percent similarities in amino acid sequences of the MP (left) and CP (right).

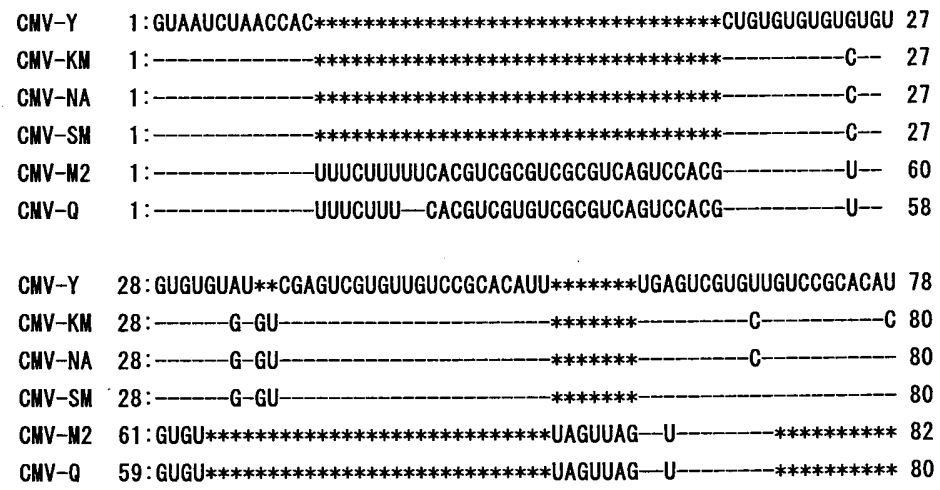

CMV-Y 79: AUAUAUUUAUUUCGUUGUACAGUGUGUUAGAUUUCCGGAGG $*$ AUG 123

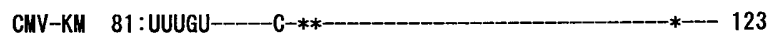

CHV-NA 81:UCUGU-_-_U-**-_-_-_-_--- 123

CHV-SM 81:UUUGU--_--C-**-_-_-_ 123

CHV-M2 $83: * * * * * * * * * * * * * * * * * * * * * * * * * * *-----\mathrm{A}-\mathrm{G} *----\mathrm{UU}---100$

CHV- 0 81:***************************---_--A-G*A---UU--- 98

Fig. 4. Alignment of the nucleotide sequences of 5'noncoding regions in RNA3 of CMV-Y, $-\mathrm{KM},-\mathrm{NA},-\mathrm{SM},-\mathrm{m} 2$ and $-\mathrm{Q}$. Common nucleotides of those of CMV-Y are represented in dashes. Deletions are represented by asterisks $\left({ }^{*}\right)$. Start codons for MP are underlined. CMV-m2 and CMV-Q belong to subgroup II. 
leaves. CMV-NA caused severe mosaic and severe leaf malformation in the upper non-inoculated leaves of tomato. CMV-NA induced small and numerous yellow spots in the inoculated leaves of Cucurbita pepo, while cotyledons of the plants inoculated with CMV-SM were asymptomatic. Whereas CMV-NA induced severe symptoms in almost all the plants tested, CMV-SM induced rather mild symptoms. N. glutinosa and R. sativus sp. inoculated with CMV-SM exhibited systemic symptoms indistinguishable from those inoculated with CMV-NA.

\section{Complete nucleotide sequence of CMV RNA3s}

The complete nucleotide sequences of CMV-NA and CMV-SM RNA3 were determined and found to be 2212 and 2216 nucleotides, respectively. RNA3s of both isolates had two ORFs encoding the MP (837nt; 279 aa) and the CP (654nt; 218 aa) (Table 2). A comparison of amino acid sequences of two proteins of CMV-NA and CMV-SM RNA3 with

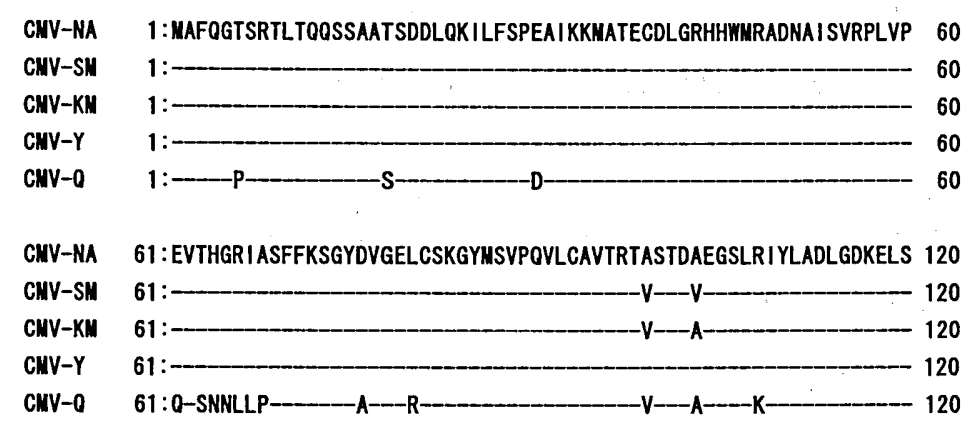

CHV-NA 121:PIDGOCVSLHNHDLPALVSFOPTYDCPNETVGNRKRCFAVVIERHGYIGYTGTTASVCSN 180

CNV-SM 121:- 180

CHV-KM 121:________________ 180

CIVY 121:- 180

CHV-0 121:-_-T--E-_- 180

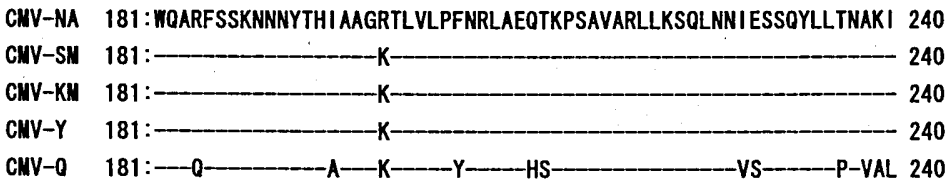

CIV-NA 241:NONARSESEE*LNVESPPAAIGSSSASRSEAFRPQVVNGL 279

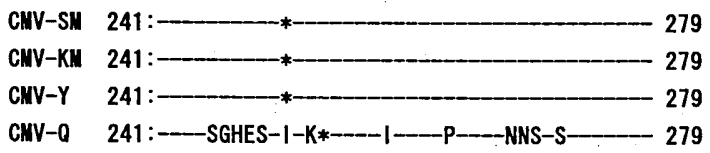

Fig. 5. Alignment of the predicted amino acid sequences of MPs of CMV-NA, $-\mathrm{SM},-\mathrm{Y},-\mathrm{KM}$ and $-\mathrm{Q}$. Common amino acids to those of CMV-NA are represented by dashes $(-)$. Deletions are represented by asterisks $(*)$. 


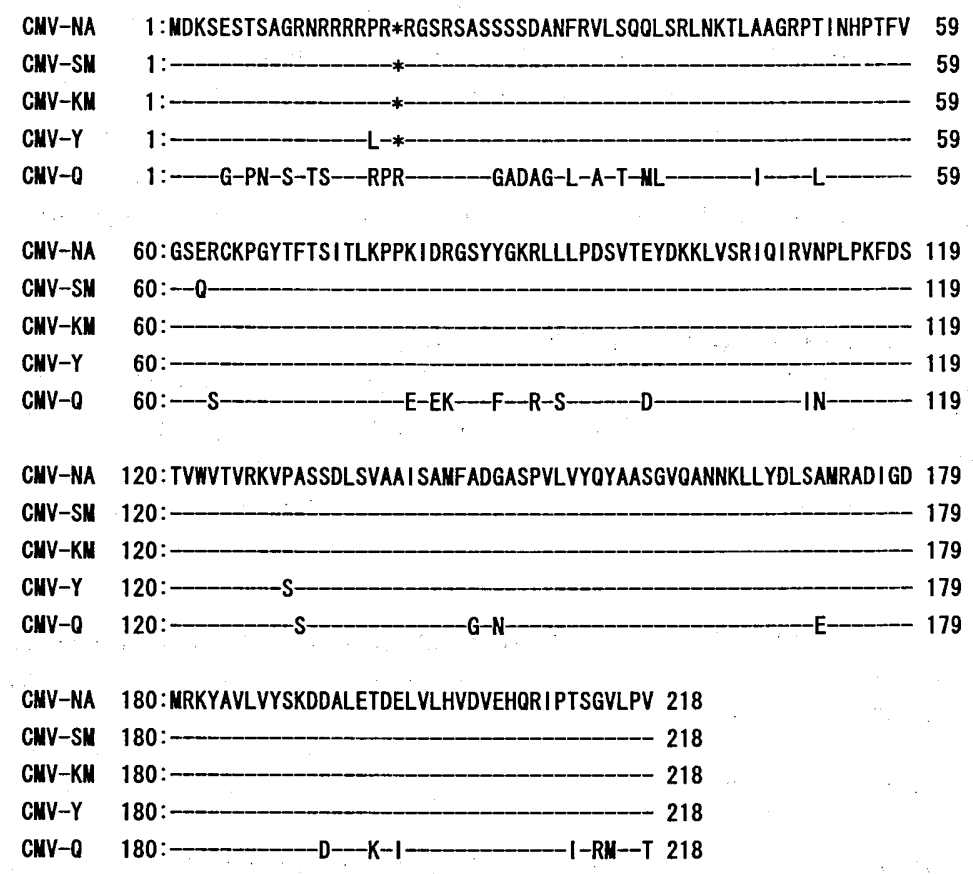

Fig. 6. Alignment of the predicted amino acid sequences of CPs of CMV-NA, $-\mathrm{SM},-\mathrm{Y},-\mathrm{KM}$ and $-\mathrm{Q}$. Common amino acids to those of CMV-Y are represented by dashes $(-)$. Deletions are represented by asterisks $\left(^{*}\right)$.

those of CMV-Y and CMV-Q revealed that the both proteins shared a high degree (over $99 \%$ ) of sequence homology with Y strain but only up to $84 \%$ with Q strain (Fig. 3). When sequences of the 5'noncoding regions of six CMV strains were aligned, those of CMV-NA and CMV-SM were highly identical to those of CMV-Y and CMV-KM strains (Fig. 4). Similar results were obtained when MPs and CPs of the five strains were aligned (Figs. 5 and 6). Differences in amino acid sequences of MP between CMV-NA and CMV-SM were due to 3 amino acid substitutions at positions 99 and 103 (A for V) and 199 ( $R$ for $\mathrm{K}$ ). Sequence analysis of the CP of CMV-NA and CMV-SM showed that there was one amino acid substitution at position 62 (E for Q) (Fig. 6).

\section{DISCUSSION}

We have characterized two CMV strains (CMV-NA and CMV-SM) inducing mild and severe systemic mosaic symptoms on tobacco, respectively, based on their complete nucleotide sequences of RNA3s and their host ranges.

Alignments of the nucleotide sequences of the 5'noncoding region of RNA3 revealed that CMV-NA and CMV-SM belong to CMV subgroup I. In addition, a comparison of the amino acid sequences of $\mathrm{CP}$ and MP also supported the same conclusion. 
CMV-NA and CMV-SM induced remarkable distinct symptoms on tobacco plants. It is of interest to mention that the amino acid sequences of the coat protein of the two isolates are identical, except for one amino acid substitution at position 62 . No references have been found about amino acid changes in that position. Further analysis including the construction of chimeras between CMV-NA and CMV-SM, and point mutants, might provide new information on whether this amino acid substitution plays a role in the difference in symptom expression or not. It was reported (Takeshita et al., 2001) that a combination of amino acids in the MP (Asn at the 51 aa) and the CP (Pro at 129 aa) of CMV determines the expression of severe chronic mosaic symptoms (SCMS), and viral spread in bottle gourd. CMV-NA and CMV-SM contains the same amino acids as CMV-KM at positions 51 and 129 of the MP and CP regions, respectively. In consistence with the result bottle gourd plants inoculated with CMV-NA expressed SCMS, but interestingly CMV-SM never induced SCMS. CMV-SM induced the similar symptomatology described for CMV-Y, occasionally expressing small yellow and necrotic spots on the first upper noninoculated leaves. This important finding indicates that there might be another factor involved in the expression of SCMS, but further studies are needed to confirm this phenomenon.

The host range test revealed significant differences between CMV-NA and CMV-SM (Table 1). For instance, $N$. occidentalis plants inoculated with CMV-SM expressed systemic mild mosaic, while no symptoms appeared by CMV-NA. Absence of virus in the asymptomatic upper leaves of the inoculated plants with CMV-NA was confirmed by RNA hybridization (Fig. 2). Cryptotaenia plants inoculated with CMV-NA showed severe leaf malformation, but no systemic infection could be detected when the plant was inoculated with CMV-NA. Thus $N$. occidentalis and $C$. japonica plants appear to be the hosts specific for CMV-SM and CMV-NA, respectively.

This is the first report describing the infection of $N$. affinis with CMV. Further analysis of the two CMV isolates belonging to the same subgroup I but inducing different severity on symptomatology might contribute to understand the mechanisms and determinants involved in symptoms expression, and to elucidate the molecular basis of the processes related to disease resistance.

\section{REFERENCES}

Adkins, S. and I. Kamenova 2003 Biological and molecular characterization of a novel tobamovirus with a unique host range. Plant Dis., 87: 1190-1196

Carrere, I., M. Tepfer and M. Jacquemond 1999 Recombinants of cucumber mosaic virus (CMV): determinants of host range and symptomatology. Arch. Virol., 144: 365-379

Grieco, F., C. Lanave and D. Gallitelli 1997 Evolutionary dynamics of cucumber mosaic virus satellite RNA during natural epidemics in Italy. Virology, 229: 166-174

Kaper, J. M. and H. E. Waterworth 1981 Cucumoviruses. In "Handbook of plant virus infection and comparative diagnosis", ed. by E. Kurstak, Elsevier/ North-Holland Biomedical Press, Amsterdam, pp. 257-332

Kobori, T., M. Miyagawa, K. Nishioka, S. T. Ohki and T. Osaki 2002 Amino acid 129 of Cucumber mosaic virus coat protein determines local symptom expression and systemic movement in Tetragonia expansa, Momordica charantia and Physalis floridiana. J. Gen. Plant Pathol., 68: 81-88

Moreno, I. M., J. J. Bernal, B. Garcia de Blas, E. Rodriguez-Cerezo and F. Garcia-Arenal 1997 The expression level of the 3 a movement protein determines differences in severity of symptoms between 
two strains of tomato aspermy cucumovirus. MPM I, 10: 171-179

Nitta, N., Y. Takanami, S. Kuwata and S. Kubo 1988 Inoculation with RNAs 1 and 2 of cucumber mosaic virus induces viral RNA replicase activity in tobacco mesophyll protoplasts. J. Gen. Virol., 69: 2695-2700

Palukaitis, P., M. J. Roossinck, R. G. Dietzgen and R. I. B. Francki 1992 Cucumber mosaic virus. Adv. Virus Res. , 41: 281-348

Roossinck, M. J., L. Zhang and K-H Hellwald 1999 Rearrangements in 5'nontranslated region and phylogenetic analyses of cucumber mosaic virus RNA 3 indicate radial evolution of three subgroups. J. Virol., 73: 6752-6758

Sanger, F. S. Nicklen and A. R. Coulsen 1977 DNA sequencing with chain-terminating inhibitors. Proc. Natl. Acad. Sci. USA, 74: 5463-5467

Shintaku, M. H., L. Zhang and P. Palukaitis 1992 A single amino acid substitution in the coat protein of cucumber mosaic virus induces chlorosis in tobacco. Plant Cell, 4: 751-757

Suzuki, M., S. Kuwata, J. Kataoka, C. Masuta, N. Nitta and Y. Takanami 1991 Functional analysis of deletion mutants of cucumber mosaic virus RNA3 using an in vitro transcription system. Virology, 183: 106-113

Suzuki, M., S. Kuwata, C. Masuta and Y. Takanami 1995 Point mutations in the coat protein of cucumber mosaic virus affect symptom expression and virion accumulation in tobacco. J. Gen. Virol., 76: $1791-1799$

Szilassy, D., K. Salanky and E. Balazs 1999 Stunting induced by cucumber mosaic cucumovirus-infected Nicotiana glutinosa is determined by a single amino acid residue in the coat protein. MPM I, 12: $1105-1113$

Takanami, Y. 1981 A striking change in symptoms on cucumber mosaic virus-infected tobacco plants induced by a satellite RNA. Virology, 109: 120-126

Takeshita, M. and Y. Takanami 1997 Complete nucleotide sequences of RNA3s of cucumber mosaic virus KM and D8 Strains. J. Fac. Agr., Kyushu Univ., 42: 27-32

Takeshita, M., M. Suzuki, S. Kuwata and Y. Takanami 1998 Involvement of cucumber mosaic cucumovirus RNA2 and RNA3 in viral systemic spread in radish plant. Arch. Virol., 143: 1109-1117

Takeshita, M., M. Suzuki and Y. Takanami 2001 Combination of amino acids in the 3a protein and the coat protein of cucumber mosaic virus determines symptom expression and viral spread in bottle gourd. Arch. Virol., 146: 697-711

Tomaru, K. and Z. Hidaka 1960 Strains of cucumber mosaic virus isolated from tobacco plants. III. A yellow strain. Bull. Hatano Tob. Exp. Sta., 46: 143-149

Walkey, D. G. A. 1991 Plant virus classification. Applied Plant Virology. Second edition. Chapman and Hall, St. Edmundsbury Press, (Great Britain) pp. 52-99

Zhang, L., K. Hanada and P. Palukaitis 1994 Mapping local and systemic symptom determinants of cucumber mosaic cucumovirus in tobacco. J. Gen. Virol., 75: 3185-3191 